\title{
The Perception on the Theory of Evolution, Man from Ape: A Cross Ethnic, Education and Religious Backgrounds Study
}

Mohd Arip Kasmo ${ }^{1}$

Abur Hamdi Usman2*
Wan Zulkifli Wan Hassan'1
Nasruddin Yunos'
Zulkifli Mohamad1
${ }^{2}$ Centre For General Studies, The National University of Malaysia, Malaysia
'Department of Theology and Philosophy, Faculty of Islamic Studies, The National University of Malaysia, Malaysia
${ }^{*}$ Corresponding Author Email: aburhamdiusman@yahoo.com

Doi:10.5901/mjss.2015.v6n1s1p338

Abstract

This study was conducted to see the perception of the Malaysian on the theory of evolution with special focus on the origin of man from ape. 640 respondents, males and females from all over the country of Malaysia were obtained randomly. The respondents come from various ethnic and religious backgrounds from the age of 20 to 50. The study used the questionnaire method whereby the respondents were given a booklet containing statements on the relation between science and religion including a statement related to the theory of evolution that man originally came from ape. The statements were provided with five responses to be chosen by the respondents. The booklets of questionnaire were collected to be analysed by using the SPSS to obtain the mean response, the mean response according to the ethnic, religious and academic background. T-test were also conducted if the means responses were significantly different. The findings show that the $77 \%$ of the Muslim respondents rejected the theory of evolution that men come from apes, $22 \%$ of the Christian, $23 \%$ of the Buddhists and $36 \%$ of the Hindu respondents rejected this theory also. The mean difference between the response of the Muslim respondents significantly different from the mean responses all the other religious groups.

Keywords: Evolution, Religion, Malaysia, Ape.

\section{Theory Evolution: The Perception Revisited}

The pertinent issue which lingers in the mind of the people with regard to the origin of human being probably is the issues where does man came from. The three main religions, Islam, Christianity and Judaism have definite answer that human being was created from Adam who was perfectly human, created out of clay (Kvam, et.al., 1999) but Charles Darwin, the $17^{\text {th }}$ century British biologist, in the name of science challenged the idea and promoted that living things including human being achieved physical perfection through the process of evolution, and that human being came from the ape (Burkhardt, et.al.,2010). There is no formal teaching of the origin of the human being from ape in the Malaysian schools but the teaching of the origin of species, excluding the origin of man is taught in biology subject (Numbers, 2006). Therefore, the theory that man came from the ape subtly crept into the mind of the people through science education. The people, through the reading of articles from various sources received the idea than man came from ape. Do they accept the theory that human being came from ape?

The level of support to the theory of evolution among the people in the world has been subjected to studies by Matthews (2014) and Matsumura (1998). Matsumura (1998) studied the level of support for evolution in the western world especially the United States, in Europe and who said that $49 \%$ of the Catholic in America accept the theory of Evolution, while the rest of the Christian denominations support on the theory of evolution are less than $10 \%$ except the South Baptist Convention whose support on the theory of evolution is $12.6 \%$. The level of support for the theory among the Catholic is not surprising because the late pope John Paul II lent his support for the theory in a in a message he gave to the Pontifical Academy of Science in 1996, in which he said new knowledge led to the recognition of the theory of evolution (Kurtz, 2001). 
A report by the Malaysian Science and Technological Information (MASTIC, 2008), only $17.5 \%$ of the Malaysian considered the Theory of Evolution to be true, $31.7 \%$ was unsure and $50.8 \%$ considered it to be untrue, while in other Muslim countries, the percentage are close to each other for example in Egypt only 8\%, in Pakistan 14\%, in Indonesia $16 \%$ and the highest percentage is in Turkey with $22 \%$ of the Turk believed that the Theory of Evolution is true. The Muslim countries such as Malaysia and Egypt are fertile ground for creationism (Muna, 2013). The Muslim traditions have in fact discussed the issues of evolution, exemplified by scholars like Ibn Maskawaih (1907) who wrote the book al-Fawaz al-Asghar and the $19^{\text {th }}$ century Indian philosopher, Iqbal (2013) who wrote the book The Reconstructions of Religious Thought.

The idea of evolution promoted by Ibn Maskawaih (1907), did not envisage human being to be last stage of human evolution but rather a stage before man evolved into the higher stage of evolution i.e. the angel. The evolution of man into the angel prove that the idea of evolution in Maskawaih mind involved the spiritual evolution. Ibn Maskawaih belief in the existence of the angel and god as stated in his theory of evolution proved that he was a believer. How did the theory of evolution crept into his mind? Like other scientists of his era, Ibn Maskawaih may have interpreted the Qur'anic verse, Chapter 21 verse 30 which talks about the evolution of the universe and the evolution of living organism. Ibn Kathir (1999), the $10^{\text {th }}$ century Muslim scholar on the Qur'an had indeed explained that the verse talks about the process of evolution of the living organism. Ibn Kathir stated that the verse which means "And We have made from water every living thing. Will they not then believe" means, "They see with their own eyes how creation develops step by step. All of that is proof of the existence of the Creator Who is in control of all things and is able to do whatever He wills" (Muna, 2013).

Iqbal (2013) also wrote about the evolution of the universe as well as the evolution of living organism. In his book The Reconstruction of Religious Thought, in which he claimed that since the World Self in the universe has a single purpose i.e. the perfection of man, it must be a single and continuous process from the beginning to its end. This is not possible unless every state of the Universe emerges and evolves out of its previous condition. This means that the universe as a whole and the various objects which make up the universe did not come into existence suddenly at a particular moment in the past but have acquired their present shape by the process of gradual development.

\section{Academic Perception of Theory Evolution: A Statistical Analysis}

The study was conducted among 640 respondents from different backgrounds including the ethnics, religions, gender, ages, academic background etc. The respondents were obtained randomly from all over the country to ensure that the respondents were not obtained in a bias manner. Each respondent was given a booklet of questionnaire containing statements on various issues of science and religion. Each statement was provided with five responses ranging from 1. Strongly disagree 2. Disagree 3. Not sure 4. Agree 5. Strongly agree. According to Domino and Domino (2006), Likert Scale is used to construct attitude scale and hence can be used in this study. The booklets of questionnaire were collected from the respondents and the raw data was analysed using the SPSS to obtain the mean response of the all respondents, the mean response of the respondents based of gender, ages, academic background, ethnic background and religious background. T-test were also conducted to see if the different of means were significant or not. The raw data were also analysed to obtain the percentage of responses responded by all the respondents, the percentage of responses based on gender, ages, academic, ethnic as well as religious background. The responses to the statement 1 which says "I accept the theory that human being originated from ape to be true". Hence, the study tried to find out how do the Malaysian society from various ethnic believe in the theory of evolution. The findings of the study can be used by the appropriate authority to plan their programme which they undertake to suit the findings of the study.

\subsection{The Findings}

The mean responses of all the respondents is shown in table 1.

Table 1: The mean response "I accept the theory that human being came from ape to be true"

\begin{tabular}{cccccc}
\hline & $\mathrm{N}$ & Minimum & Maximum & Mean & Std. Deviation \\
\hline \multirow{2}{*}{ Valid N } & 1288 & 1.00 & 5.00 & 2.1351 & 1.31292 \\
\hline
\end{tabular}

Table 1 shows that the mean response is 2.1351 which is lower than 3 . This means that the respondents generally rejected the theory that human being originated from ape, but the rejection is not strong enough. Moreover, the next 
analysis was to obtain the mean responses for the respondents according to the religion. Table 2 shows the mean response according to religion.

Table 2. The mean response according to religion

\begin{tabular}{lccc}
\hline Religion & Mean & $\mathrm{N}$ & Std. Deviation \\
\hline Islam & 1.7624 & 442 & 1.18193 \\
Christianity & 2.8814 & 59 & 1.34016 \\
Buddhism & 3.0989 & 91 & 1.10609 \\
Hinduism & 2.8333 & 48 & 1.22619 \\
\hline
\end{tabular}

Table 2 shows that the mean response of the Muslim respondents is 1.7624 , the Christians mean response is 2.8814 , the mean response for the Buddhists was 3.0989 and the mean response for the Hindu was 2.8333. The finding shows that the Muslim respondents were the strongest group to reject the statement, followed by the Hindu, the Christian and the Buddhists. The next test was to see if the difference of means is significant or not. The result of the t-test is shown in table 3.

Table 3. T-test between of the mean response of the Muslim respondents and the mean response of Christian respondents

\begin{tabular}{ccccc}
\hline $\mathrm{F}$ & Sig. & $\mathrm{t}$ & $\mathrm{df}$ & Sig. (2-tailed) \\
\hline 3.167 & .076 & -6.719 & 499 & .000 \\
& & -6.104 & 70.569 & .000 \\
\hline
\end{tabular}

Table 3 shows that the $p$ value at the critical value of $95 \%$ is 0.00 which is smaller than the critical value of 0.05 which indicates that the difference of mean is significant. Therefore, it can be concluded that the difference of mean between the Muslim mean response and the Christian mean response and the different is significant. As a further matter, the difference of mean between the Muslim response and the Buddhists were tested. The result of the test is shown in the table 4.

Table 4. The t-test between the Muslim response and the Buddhist response

\begin{tabular}{ccccc}
\hline $\mathrm{F}$ & Sig. & $\mathrm{t}$ & $\mathrm{df}$ & Sig. (2-tailed) \\
\hline 3.453 & .064 & -9.928 & 531 & .000 \\
& & -10.371 & 135.757 & .000 \\
\hline
\end{tabular}

Table 4 shows that the $p$ value is 0.000 which is smaller than the critical value of 0.05 . This indicates that the difference between the mean response of the Muslim respondents and the Buddhist respondents is significant. Besides it, the mean difference between the Christian response and the Hindu response was also tested to see of the mean difference is significant or not as shown in the table 5.

Table 5. The t-test between the mean response of the Christian and the Hindu

\begin{tabular}{ccccc}
\hline $\mathrm{F}$ & Sig. & $\mathrm{t}$ & $\mathrm{df}$ & Sig. (2-tailed) \\
\hline .857 & .357 & .191 & 105 & .849 \\
& & .193 & 103.516 & .847 \\
\hline
\end{tabular}

Table 5 shows that the $p$ value is 0.849 and the value is greater than the critical value of 0.05 . This shows that the difference of mean between the Christian respondents and the Hindu respondents is significant. Furthermore, the difference of mean between the Christian respondents and the Buddhists respondents is also tested as shown in the table 6.

Table 6. The t-test between the mean response of the Christian and the Buddhists

\begin{tabular}{ccccc}
\hline $\mathrm{F}$ & Sig. & $\mathrm{t}$ & $\mathrm{df}$ & Sig. (2-tailed) \\
\hline 6.830 & .010 & -1.082 & 148 & .281 \\
& & -1.038 & 107.084 & .301 \\
\hline
\end{tabular}

Table 6 shows that the $p$ value, 0.281 is greater than the critical value at $95 \%$ confidence limit which is 0.05 . This indicates that the mean difference between the mean response of the Christian and the Buddhists is not significant. In 
addition, the last t-test is between the mean difference between the Buddhists and the Hindu. The result of the test is shown in table 7.

Table 7. The t-test between the mean difference of the Buddhists and the Hindu

\begin{tabular}{ccccc}
\hline $\mathrm{F}$ & Sig. & $\mathrm{t}$ & $\mathrm{df}$ & Sig. (2-tailed) \\
\hline 2.233 & .137 & 1.296 & 137 & .197 \\
& & 1.255 & 87.578 & .213 \\
\hline
\end{tabular}

Table 7 shows that the $p$ value is 0.197 which is smaller the 0.05 , which is the critical value at $95 \%$ confidence limit. Hence, the significance of the difference of the mean according to the religion can be seen in the table8.

Table 8. The mean response according to the religion

\begin{tabular}{lcccc}
\hline & Muslim & Christian & Buddhist & Hindu \\
\hline Muslim & & $\checkmark$ & $\checkmark$ & $\checkmark$ \\
Christian & $\checkmark$ & $\mathrm{x}$ & $\mathrm{x}$ & $\mathrm{x}$ \\
Buddhist & $\checkmark$ & $\mathrm{x}$ & $\mathrm{x}$ & $\mathrm{x}$ \\
Hindu & $\checkmark$ & $\mathrm{x}$ & $\mathrm{x}$ & $\mathrm{x}$ \\
\hline
\end{tabular}

Table 8 shows that the difference of mean is only significant between the mean of the Muslim respondents and the rest of the other religions while among the religion, the difference of mean are not significant. Thus, the significance of the difference of the mean according to the ethnics can be seen in the table 9 .

Table 9. The mean response according to the ethnics

\begin{tabular}{lccc}
\hline Ethnic & Mean & $\mathrm{N}$ & Std. Deviation \\
\hline Malay & 1.7620 & 437 & 1.17040 \\
Chinese & 3.0407 & 123 & 1.19698 \\
Indian & 2.8571 & 56 & 1.18212 \\
Sabah Native & 2.4091 & 22 & 1.46902 \\
Sarawak Native & 3.7500 & 4 & 1.89297 \\
\hline
\end{tabular}

Table 9 shows that the mean response of the Malays is the highest, followed by the Sabah native, Indian and the Chinese and by the Sarawak native. The mean response of the Sarawak native is 3.7500 while the mean response of the Chinese is 3.0407. The mean response of the Chinese is very close to the mean response of the Buddhists which is 3.0989. The mean is almost the same can be explained from the table 10 which show the religion of the ethic group. Most of the Chinese are Buddhists and that could explain why the mean response of the Chinese and the Buddhists are close to each other.

Table 10. The ethnic and religion of the respondents

\begin{tabular}{|c|c|c|c|c|c|c|c|c|c|c|}
\hline \multirow[b]{2}{*}{ Islam } & \multicolumn{2}{|c|}{ Malay } & \multicolumn{2}{|c|}{ Chinese } & \multicolumn{2}{|c|}{ Indian } & \multicolumn{2}{|c|}{$\begin{array}{l}\text { Sabah } \\
\text { Native }\end{array}$} & \multicolumn{2}{|c|}{$\begin{array}{c}\text { Sarawak } \\
\text { Native }\end{array}$} \\
\hline & 437 & 100 & 2 & 1.8 & 0 & 0.00 & 7 & 31.8 & 2 & 50 \\
\hline Christian & 0 & 0.00 & 32 & 28.6 & 7 & 12.5 & 13 & 59.1 & 2 & 50 \\
\hline Buddha & 0 & 0.00 & 88 & 78.6 & 1 & 1.8 & 2 & 9.1 & 0 & 0 \\
\hline Hindu & 0 & 0.00 & 0 & 0.0 & 48 & 85.7 & 0 & 0.00 & 0 & 0 \\
\hline Total & 437 & 100 & 112 & 100 & 56 & 100 & 22 & 100 & 4 & 100 \\
\hline
\end{tabular}

Table 10 shows that the majority of the Chinese are Buddhists (78.6\%). The result explains why the mean of the Chinese respondents is close to the mean response of the Buddhists. Additionally, the next analysis was to analyse the percentage of each responses. The following table 11 shows the percentages of the responses. 
Table 11: The percentage of the response

\begin{tabular}{lcccc}
\hline & Frequency & Percent & Valid Percent & Cumulative Percent \\
\hline Strongly disagree & 630 & 48.8 & 48.9 & 48.9 \\
Disagree & 176 & 13.6 & 13.7 & 62.6 \\
Not sure & 242 & 18.8 & 18.8 & 81.4 \\
Agree & 158 & 12.2 & 12.3 & 93.6 \\
Strongly agree & 82 & 6.4 & 6.4 & 100.0 \\
\hline
\end{tabular}

Table 11 shows that the percentage for response 1 which is strongly disagree with the statement is $48.9 \%$, disagree is $13.7 \%$. Altogether those respondents who rejected the statement was $62.6 \%$. The percentage of those who were not sure was $18.8 \%$, those who agreed with the statement was $12.3 \%$ and those who strongly agree with the statement was $6.4 \%$. Altogether those who accepted the statement was 240 respondents representing 18.7\%. The percentages of the responses are plotted into a line graph as shown in Figure 1.

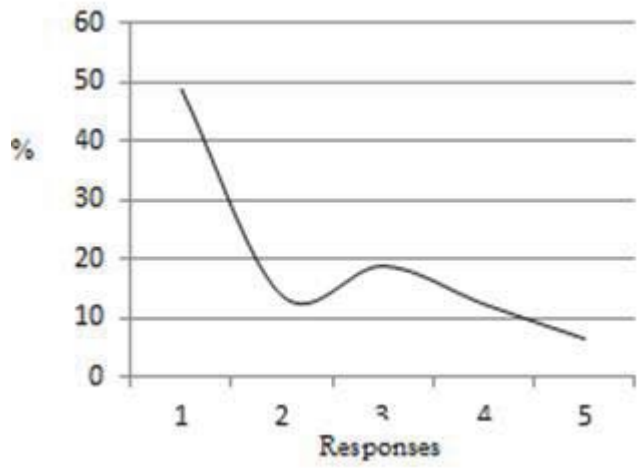

Figure 1. The percentage of response

Figure 1 shows the percentages of the general responses of all the respondents and the graph show that the rejection of the theory of evolution that man originated from ape was high from response 1 which is strongly disagree to lowest for response 5 which is strongly agree. Likewise, the next analysis was to obtain the percentages of the responses according to the religious background as shown in table 12 .

Table 12. The percentage of the responses according to the religion.

\begin{tabular}{lcccccccc}
\hline & \multicolumn{2}{c}{ Islam } & & Christianity & Buddhism & \multicolumn{2}{c}{ Hinduism } \\
\hline Strongly disagree & 279 & 63.00 & 14 & 24.0 & 10 & 11.0 & 10 & 21.0 \\
Disagree & 61 & 14.00 & 8 & 14.0 & 11 & 12.0 & 7 & 15.0 \\
Not sure & 52 & 12.00 & 14 & 24.0 & 40 & 44.0 & 15 & 31.0 \\
Agree & 28 & 6.00 & 17 & 29.0 & 20 & 22.0 & 13 & 27.0 \\
Strongly agree & 22 & 5.00 & 6 & 10.00 & 10 & 11.0 & 3 & 6.0 \\
\hline Total & 442 & 100 & 59 & 100 & 91 & 100 & 48 & 100 \\
\hline
\end{tabular}

Table 12 shows the percentages of the responses according to the religion. 11\% of the Muslim respondents accepted the theory, $39.0 \%$ of the Christian, $33 \%$ of the Buddhists and $33.3 \%$ of the Hindu accepted the theory of Evolution.

\section{Discussion}

The study shows that generally the respondents rejected the theory of evolution, with the mean response of 2.135 , which lies between 2 (disagree) and 3 (not sure). The analysis which is based religious background shows that the Muslim mean response is the smallest, meaning that the Muslim is the religious group which about $18 \%$ of the respondent support the theory of evolution which says human being originated from ape. Taking into account the randomness of the respondents, it can be deduced from the study that $18 \%$ of the respondents accepted the Theory of Evolution to be true and this percentage tallies with the percentage released by the Malaysian Science and Technology Information Centre 
(2008) which gave the percentage to be $17.5 \%$, and the percentage is based on the general masses, disregarding the ethnicities of the respondents.

The percentages of acceptance of the theory of evolution among other religious group fall within the same range between $30 \%$ to $40 \%$. The difference of acceptance of the theory of evolution especially between the Muslim and the other religious group seem to be significant and there are ample factors which led to this. One the reason was that Muslim in Malaysia are traditionally strict adherer to the Islamic religion. Islamic education within the Muslim society in Malaysia is well entranced, especially in the Islamic education which is taught in the government schools, from the primary level up to the upper secondary level and also by the private schools and the informal education in the mosques and other places. The Muslims are taught, as what has been described by the Qur'an and the Hadith (prophetic tradition) that human being was created from the soil, formed into the perfect human being and, and out of him, was created Ave. They lived in the garden of heaven until they transgressed the rule stipulated by Allah not to eat the fruit, after which they were ejected into the earth. The teaching of the origin of man is part and parcel of the teaching of Islam and the people receive the idea that man came from ape from various secondary sources such as from the television programmes, magazines etc.

The book written by Bucaille (2005), What is The Origin of Man, highlighted further the issue of the origin of man, from ape and the explanation by Bucaille (2005) further strengthened the rejection of man from ape. For Muslim to reject the theory of Evolution does not affect the Muslim view of modern science. Many Muslims view that science does not contradict religion and even science does not contradict the Qur'an except for the theory of Evolution. The conflicts between creationism and evolutionism does exist in the Muslim society because the Qur'an itself mention some major issues of science such as cosmology, astronomy, oceanography, embryology, geology etc which are perfectly in agreement with the scientific findings. And the Qur'an mentions the origin of the universe as well the aquatic origin of all living organism as stated in chapter 21 verse 30 "Do not the Unbelievers see that the heavens and the earth were joined together (as one unit of creation) before we clove them asunder? We made from water every living thing. Will they not the believe?". Although this verse clearly says that living organism originated from water, which is similar to the assertion of the theory of evolution which claimed the first living organism came out of water in the form of simple single cell which later undergone cell divisions, from thence on evolution took place.

Ibn Kathir (1999), stop short of relating the verse to the embryological development of human being in the womb of mother. On the other hand, Ibn Maskawaih (1907) promoted the idea of evolution in plants and animals in his book alFawz al-Azghar and his work may have influenced Charles Darwin. Ibn Maskawaih (1907) puts up the theory of evolution in plants. According to Ibn Maskawaih (1907), plants evolved from simple form to the complex form while on the other hand animals evolved from plant. The highest form of plants posses the animals characters and that character indeed prelude to the evolution of animal. According to Ibn Maskawaih (1907), the sense of touch was the first to appear for the animals to be and the last to appear was the sense of sight. With the development of the sense, the animal achieved freedom of movement. Animal reached perfection in the horse among the quadrupeds and falcon among the bird.

The evolution, according to Ibn Maskawaih (1907) arrived at the frontier of human being in ape. The ape continued to evolve physiologically until human being was transformed from barbarism to civilisation. The Muslim response to the statement reflects that the education they received in the schools has successfully convinced them that Adam, who was the first human was created in perfect human form, not through evolution from simple organism which came out of water and through long period evolved into various species including ape and ultimately to the human species. The Muslim rejection on the theory of evolution may be associated with the belief that The God could do whatever He wishes to do, but the Muslim should also believe that The God creates something systematically, not haphazardly through the natural law. The rejection of the majority of respondents on the theory of Evolution is theological in nature, since majority of the Muslim are afraid that accepting the theory is akin to blasphemy.

The finding has also shown that the response of the non-Muslim, where between 30 to $40 \%$ accept the theory which says man originated from ape. Although Christianity description of the origin of man is almost similar to Islam, the church authority has endorsed the theory of evolution and hence many Christian subscribed to the idea of creation (Schroeder, 2013). Buddhism and Hinduism do not have a specific description on the origin of man and hence this is the reason why higher percentages of the Buddhists and Hindu respondents accepted the theory of evolution.

\section{References}

Bucaille, M. (2005). What is The Origin of Man. India: Islamic Book Service.

Burkhardt, F. et. al. (2010). The Correspondence of Charles Darwin. Volume 18, 1870. Cambridge: Cambridge University Press.

Domino, G. \& Domino, M. L. (2006). Psychological Testing: An Introduction. Cambridge, UK: Cambridge University Press. 
Ibn Kathir, I. (1999). Tafsir al-Qur'an al-Azim. Vol. 5. Cairo: Dar Tayyibah.

Ibn Miskawaih, A. M. (1907). al-Fawaz al-Așghar. Damascus: Mațba'ah al-Sa‘ādat.

Iqbal, M. (2013). The Reconstruction of Religious Thought in Islam. London: Stanford University Press.

Kurtz, P. (2001). Skepticism and Humanism: The New Paradigm. New Jersey: Transaction Publishers.

Kvam, K. E. et. al.(1999). Eve and Adam: Jewish, Christian, and Muslim Readings on Genesis and Gender. Indiana: Indiana University Press.

Malaysian Science and Technological Information Centre. (2008). Malaysian Research and Development Classification System 5th Edition. Kuala Lumpur.

Matsumura, M. (1998). Voices for Evolution. Berkeley: National Centre for Science Education.

Matthews, M.R. (2014). International Handbook of Research in History, Philosophy and Science Teaching. London: Springer.

Muna, A. (2013). Debates on Islam and Knowledge in Malaysia and Egypt. Routledge, New York: Shifting Worlds.

Numbers, R. L. (2006). The Creationists: From Scientific Creationism to Intelligent Design. Harvard: Harvard University Press.

Schroeder, J. (2003). Heresies of Catholicism... The Apostate Church. United Kingdom: IUniverse,Inc. 